\title{
2005-06 Farm Bill Survey: Characteristics of Florida Producers Who Participated ${ }^{1}$
}

Rodney L. Clouser ${ }^{2}$

\section{Introduction}

The Farm Security and Rural Investment Act of 2002 (also known as the 2002 U.S. Farm Bill) authorizes many federal farm programs through 2007. Before this authorization expires, congressional action is expected for future federal farm programs and development of a new comprehensive Farm Bill. While expiration of the 2002 Act is still several months in the future, the discussion of potential new legislation has already started. The current congressional focus on budget priorities and spending levels at the national level and the negotiation of international trade agreements will certainly influence debate on the next Farm Bill. During deliberations for the next Farm Bill, information regarding alternatives and preferences becomes important in the decision-making process. Land grant universities and Extension policy specialists have contributed to past Farm Bill deliberations by providing information on producer preferences. This information has been gathered through surveys of producers coordinated by state Extension specialists under the support of the National Public Policy Education Committee and the Farm Foundation in coordination with the National Agricultural Statistics Service of USDA.
Florida was one of 27 states which participated in a farm producer survey concerning attitudes and views regarding U.S. Congressional enactment of the next farm bill. The survey was completed in the winter of 2005-06. Nationally, data for all states participating in the survey were entered and complied at the University of Nebraska.

This fact sheet is one in a series of four reporting information collected from Florida producers:

1. Socioeconomic characteristics of Florida farm producers completing the survey (FE663).

2. Specific views of Florida producers on inclusion of fruit, vegetable, and specialty crops in federal government commodity programs; views of producers if government funding is focused on open space and farmland preservation; preferences related to rural development programs; allocation of research funds among various program areas and labor issues affecting agriculture (FE664).

3. Views on conservation, environmental, trade, and food system and regulatory policies (FE665).

1. This is EDIS document FE663, a publication of the Food and Resource Economics Department, Florida Cooperative Extension Service, Institute of Food and Agricultural Sciences, University of Florida, Gainesville, FL. Published October 2006. Please visit the EDIS website at http://edis.ifas.ufl.edu.

2. Rodney L. Clouser, Professor, Food and Resource Economics Department, Florida Cooperative Extension Service, Institute of Food and Agricultural Sciences, University of Florida, Gainesville, FL.

The Institute of Food and Agricultural Sciences (IFAS) is an Equal Opportunity Institution authorized to provide research, educational information and other services only to individuals and institutions that function with non-discrimination with respect to race, creed, color, religion, age, disability, sex, sexual orientation, marital status, national origin, political opinions or affiliations. U.S. Department of Agriculture, Cooperative Extension Service, University of Florida, IFAS, Florida A. \& M. University Cooperative Extension Program, and Boards of County Commissioners Cooperating. Larry Arrington, Dean 
4. Florida producer views on farm programs and budget priorities, and commodity programs and risk management (FE666).

This fact sheet reports on the socioeconomic characteristics of Florida farm producers completing the survey.

Florida farm producers have participated in these surveys just prior to enactment of each new farm bill legislation since 1985. Of the 27 states participating in the survey, five were from the South: Alabama, Florida, Georgia, North Carolina and Texas. Nationally, southern states accounted for about 30 percent of all farms included in the statistical analysis. In total, the southern and north central regions accounted for 76 percent of farms used for statistical analysis.

\section{Farm Producer Survey Questionnaire}

Questionnaires were mailed to over 1,900 Florida producers during the winter of 2005-06. Approximately 15.4 percent of the surveys (294) were returned by the designated return date. An additional 21 (1.1 percent) surveys were returned after the designated return date and were not forwarded to the University of Nebraska for inclusion in the responses. Of the 294 surveys returned by the designated return date, 33 producers answered none of the survey questions, so those surveys were classified as not valid. In addition, 17 producers returned surveys but did not answer a question concerning the market value of their farm sales. For statistical purposes, the reporting of farm sales was necessary to ensure proportional representation in the national summary. The 17 Florida producers who returned surveys but failed to answer the farm sales question were considered to have returned valid but non-usable surveys. Therefore, the total number of valid and usable surveys in Florida was 244.

\section{Age, Gender, and Race}

The average age of Florida producers participating in the survey was almost 56-years-old using the mid-points of the six age ranges included in the questionnaire. About one-third of all producers were in the 45-54 age range. At the same time, there were no producers responding who were 25 -years-old or younger. More than half the producers responding were above the age of 55 .

Eighty-five percent of survey participants were male and 15 percent female. Just over seven percent of participants considered themselves of Spanish, Hispanic, or Latino origin. Over 93 percent of survey respondents considered their racial classification as white, and almost three percent classified themselves racially as black. The remaining three percent were members of other racial minority groups.

\section{Farm Sales and Farm Income}

Seven categories of farm sales data were collected in the survey (Table 1). These categories were then summarized into three categories: less than $\$ 100,000$; sales above $\$ 100,000$ but less than $\$ 250,000$; and sales above $\$ 250,000$. Just slightly more than 74 percent of those surveyed had sales less than $\$ 100,000$. Almost 12 percent of those in the survey had farm sales between $\$ 100,000$ and $\$ 249,999$. Just over 14 percent had sales greater than $\$ 250,000$. The largest number of producers (34 percent) completing the survey had sales of less than $\$ 10,000$. On the other extreme of the scale, two percent had sales greater than $\$ 500,000$ but less than $\$ 999,999$ and six percent reported farm sales greater than $\$ 1,000,000$.

Producers were asked to define a small farm in the survey. The largest category of individuals (23.4 percent) indicated a small farm had less than $\$ 50,000$ in sales. Another 22.6 percent indicated that small farms could not be easily defined. In total, 52.6 percent of everyone surveyed indicated that small farms had sales less than $\$ 100,000$. Almost four percent of all surveyed indicated that farms with sales less than $\$ 1,000,000$ would be considered small.

Thirty-eight producers (15.6 percent) reported farm sales of organic products. Over 51 percent (125) reported only farm sales of crops, 24.6 percent (59) reported only sales of livestock, and 24.6 percent (59) reported sales of both crops and livestock. Individually, the top three commodities produced by those completing the survey were fruit and tree nuts (73); cattle and calves (62); and nursery, greenhouse, floriculture, and sod (62). Almost 72 percent 
indicated they earned less than 50 percent of their family income from farming and ranching. That means only about one out of every four survey participants earned more than 50 percent of family income from farming and ranching.

\section{Education}

The technical nature and business skills required to succeed in modern production agriculture are becoming more apparent over time and may be reflected by producer educational attainment levels (Table 2). Just over 78 percent of respondents had either attended a college or technical school. Approximately 28.1 percent had graduated with a bachelor's degree and an additional 14.9 percent had graduated with an advanced college degree. On the other end of the scale, only 3.2 percent had left school before completing their high school/GED equivalent. A similar survey conducted at the University of Florida prior to the 1990 farm bill survey indicated that only about 50 percent of producers surveyed had technical or college training.

\section{Past Participation in Government Programs}

Producers responding to the survey were asked to indicate government programs they had participated in recently. Only three farm programs had participation from more than 10 percent of those surveyed. Almost 37 percent indicated they had participated in programs related to disaster assistance. Crop and livestock insurance programs had been used by 13.5 percent of those surveyed. Finally, 10.6 percent of those surveyed had participated in commodity programs such as direct payments, price supports, and commodity loans. In general, especially compared to north central and western states, Florida does not produce a large number of crops eligible for federal commodity programs.

\section{Land Ownership and Future Use}

Almost 73 percent of those surveyed own between 75 and 100 percent of the land that is part of the farm operation (Table 3 ). Only 23.5 percent own less than 50 percent of the land they farm. In response to the question,"When you are no longer operating your farm or ranch, what do you expect will happen to the operation?", almost 44 percent said their expectation was that the current farm would be converted to non-farm use. That most likely implies those producers expect the current operation to be developed commercially or residentially. Almost 33 percent expect their children to operate the farm operation in the future.

\section{Summary}

The 244 valid surveys returned by Florida producers represent varied backgrounds, interests and characteristics. Most of the producers own their land and most expect it to eventually to be converted to non-farm purposes when they no longer farm. Almost 75 percent of those surveyed had farm sales of less than $\$ 100,000$ and over 75 percent had attended or graduated from technical schools or colleges. About 51 percent sold only crops and about 25 percent reported sales of livestock, with cattle as the primary enterprise.

\section{References}

Clouser, Rodney L., and Steve Ford. 1990. A 1990 Farm Bill Survey: Characteristics of Florida Producers Who Participated. FRE Extension Notes EN-19. Food and Resource Economics Department, University of Florida, Gainesville, FL (April).

Lubben, Bradely D. 2006. National Agricultural, Food and Public Policy Preference Survey Database Documentation. Department of Agricultural Economics, University of Nebraska, Lincoln, NB (May). 
Table 1. Annual value of farm sales.

\begin{tabular}{|lc|}
\hline \hline Annual Value of Farm Sales & Percent \\
\hline Under $\$ 10,000$ & 34 \\
$\$ 10,000$ to $\$ 49,999$ & 25 \\
$\$ 50,000$ to $\$ 99,999$ & 15 \\
$\$ 100,000$ to $\$ 249,999$ & 12 \\
$\$ 250,000$ to $\$ 499,999$ & 6 \\
$\$ 500,000$ to $\$ 1,000,000$ & 2 \\
Over $\$ 1,000,000$ & 6 \\
\hline \hline
\end{tabular}

Table 2. Last year of scholl completed.

\begin{tabular}{|lc|}
\hline \hline Last Year of School Completed & Percent \\
\hline Grade School & 1 \\
Some High School & 2 \\
High School or GED & 19 \\
Some College or Technical School & 35 \\
College Bachelor's Degree & 28 \\
Advanced College Degree & 15 \\
\hline \hline
\end{tabular}

Table 3. What will happen to the farm after you no longer operate it?

\begin{tabular}{|lc|}
\hline \hline Future Farm Operations & Percent \\
\hline Operated by Spouse & 6 \\
Operated by Children & 33 \\
Operated by Other Relative(s) & 5 \\
Operated by Non-Relative Currently Involved & 4 \\
Operated by Non-Relative Not Currently Involved & 9 \\
Converted to Non-Farm Use & 44 \\
\hline \hline
\end{tabular}

